\title{
Are Christian Arabs the New Israeli Jews? Reflections on the Educational Level of Arab Christians in Israel
}

\author{
Hanna David \\ School of Education, University of Tel Aviv, Jerusalem, Israel
}

\begin{abstract}
In 1949, a year after the establishment of the state of Israel, Christian Arabs consisted of $2.9 \%$ of the population in the newly born Israel, and $21.25 \%$ of all Arabs living in it. ${ }^{1}$ In 2010 the rate of Christian Arabs decreased to just $1.8 \%{ }^{2}$ of the Israeli population, and only $~ 9.5 \%$ of all Arabs holding an Israeli ID $^{3}$ (Statistics, Israel, 2012, Table 2.2). The tendency of decrease in the rate of Christians in Israel is clear when examining the rate of first grade children in comparison to that of the general population: In the 2010/11 school year Christian Arabs consisted only of about 1.6\% of first grade students (Statistics, Israel, 2009, table 8.24 ) in comparison to their $1.8 \%$ rate in the population.
\end{abstract}

Keywords: religion; Christian Arabs; Israel; educational level

\section{INTRODUCTION}

Data published by Central Bureau of Statistics revealed that at the end of 2012158,000 Christians lived in Israel, making up $2 \%$ of population. $80.6 \%$ of them were Arabs (Druckman, 23/12/2012). The CBS data revealed that $71 \%$ of Arab Christians resided in the northern district of the country, $13 \%$ in the Haifa district and only $9.5 \%$ in the Jerusalem area. The communities with the largest number of Arab Christian residents were Nazareth with 22,400, Haifa with 14,400, Jerusalem with 11,700 and Shfaram with 9,400 (ibid).

\footnotetext{
${ }^{1}$ Processed from Statistics, Israel, 2009, table 2.2. Retrieved on July 22, 2013 from

http://www.cbs.gov.il/reader/shnaton/templ_shnaton.html?num_tab=st02_02\&CYear=2009

${ }^{2}$ Processed from Statistics, Israel, 2012, table 2.2. Retrieved on July 222013 from http://www.cbs.gov.il/shnaton63/st02_02.pdf

${ }^{3}$ While the term for "Arabs who are Israeli citizens", used mainly by Israeli institutions is "Israeli Arabs". Many Arabs living in Israel and holding an Israeli citizenship prefer the term: "Palestinians" or "Palestinian Arabs". Some of them, along with Arabs living in Arab countries, use the term: "Arabs of 48" [عرب 48].
} 


\section{SOME DEMOGRAPHIC CHARACTERISTICS OF CHRISTIANS IN ISRAEL}

Arab Christians living in Israel have been much more similar to Israeli Jews in most aspects of life. For example: about a half of Arab Christian families had in 2012 at least one child under 17 - in comparison to $45 \%$ of Jewish families and $71 \%$ of Muslim (ibid).

In terms of child-birth, in 2011 the average number of children born to a Christian mother stood at 2.2, and was the lowest birth rate among all religious groups in Israel. In comparison, a Muslim woman will bear an average of 3.5 children during her lifetime, a Jewish woman 3.0 and a Druze 2.3 (ibid).

In addition, the median marriage age for Christian Arab bridegrooms was 29.3, about a year and a half higher than that of Jews, and of brides -24.5 , about one year less than that of Jews (ibid). Taking into consideration that most Christian Arab males and practically all Christian Arab females do not serve in the Israeli army, Christian Arab males had an advantage of about 4.5 years for requiring education and establishing a stable professional standing before getting married over Jews, while Christian Arab girls had an advantage of about one year over Jewish females to complete their education and starting their professional life before taking over the commitments of married life. The relatively high age of marriage among Christian males, and the high educational levels of both males and females among Christian Arabs have a substantial contribution to the success and stability of their marriage, as has been shown both in Israel (Fridman, 2011) and abroad (e.g. Lehrer, 2006).

\section{CHRISTIAN STUDENTS: THE VANGUARD IN EDUCATION}

In spite of the fact that in a population of 8-million Christian Arabs have been a small minority, they have had a substantial impact on Israeli life, especially in participation in high level education and subsequently - in the professions.

For many years Christian Arabs in Israel have enjoyed the highest levels of matriculation and educational achievement. They have ranked highest by all criteria including the best quality of the matriculation certificate, especially with respect to the number of units studied in high school and the number of scientific areas taken during high school at the highest possible level. As good quality of high school education is a main requirement for upper education, the result has been that the rate of high school graduates who have earned university degrees has also been very high (Ratner, 2005; Talal, \& Ben Rabi, 2001; Weingard, 2001).

The educational achievements of Christian Arabs in Israel are masked by the way it represented by the authorities: as part of the "Arab" population. Thus, when not looking at the data published by the Israeli Central Bureau of Statistics [CBS] (Statistics, Israel, 1999, 2000, 2001, 20002, 2003, 2004, 2005, 2006, 2008, 2009, 2010, 2011, 2012) in depth, namely, at the results of Christian students at all levels apart from those of Muslims, Druze, and Bedouins, the very high achievements of the Christians do not shine because they do not contribute but a little to the "Arab" achievements, as Christians are but a small minority of all Arab students. However, the CBS noted that when taking into account the data recorded over the years, Christian Arabs fared the best in terms of education in comparison to any other group receiving an education in Israel. For example: in 2011 the number of Arab Christian students eligible for a high-school diploma stood at $64 \%$ in comparison to only $48 \%$ among Muslim children, $55 \%$ among Druze and 59\% in the Jewish education system in general (Statistics, Israel, 2012, table 8.24). 
The advantage of Christian Arabs over Jews is even lager considering the fact that $95.5 \%$ of grade 12 Christian Arab students took the matriculation exams in comparison to only $81.9 \%$ of Jews (ibid). Furthermore: while 55.7\% of the Christian Arabs met university entrance requirements, the rate among Jews was only $49.3 \%$ (ibid).

Christian students were also the vanguard in terms of eligibility for higher education. Some $56 \%$ of Arab Christians, compared with $50 \%$ of Jewish students; $36 \%$ of Druze students and only $34 \%$ of Muslims received a high school diploma that met the basic demands of Israeli universities. Let us look at the data demonstrating the advantage of Christian students in matriculation results and in eligibility to higher education.

Table 1. Non-Jewish and Jewish $12^{\text {th }}$ graders in Israel: 2010/2011 .

\begin{tabular}{|c|c|c|c|c|c|c|c|c|}
\hline \multirow[b]{2}{*}{ Muslim } & \multicolumn{2}{|c|}{$\begin{array}{c}12^{\text {th }} \text { graders No. } \\
(\%)\end{array}$} & \multicolumn{2}{|c|}{$\begin{array}{c}\text { Took } \\
\text { matriculation } \\
\text { exams No. }(\%)\end{array}$} & \multicolumn{2}{|c|}{$\begin{array}{c}\text { Entitled to } \\
\text { certificate No ( } \% \\
\text { of } 12^{\text {th }} \text { graders) }\end{array}$} & \multicolumn{2}{|c|}{$\begin{array}{l}\text { Met university } \\
\text { entrance } \\
\text { requirements } \\
\text { (\% of } 12^{\text {th }} \\
\text { graders) }\end{array}$} \\
\hline & 16759 & & $\begin{array}{l}15280 \\
(91.2)\end{array}$ & & $\begin{array}{c}7693 \\
(45.9)\end{array}$ & & $\begin{array}{c}5548 \\
(33.1)\end{array}$ & \\
\hline Christian & 1849 & & $\begin{array}{c}1765 \\
(95.5)\end{array}$ & & $\begin{array}{l}1,163 \\
(62.9)\end{array}$ & & $\begin{array}{c}1027 \\
(55.7)\end{array}$ & \\
\hline Druze & 2089 & & $\begin{array}{c}2018 \\
(96.6)\end{array}$ & & $\begin{array}{c}1144 \\
(54.8)\end{array}$ & & $\begin{array}{c}817 \\
(39.1)\end{array}$ & \\
\hline All Arabs & 20774* & $\begin{array}{c}\text { Boys: } \\
9312 \\
(44.8) \\
\text { Girls: } \\
11462 \\
(55.2)\end{array}$ & $\frac{19117}{\underline{(92.0)}}$ & $\begin{array}{c}\text { Boys: } \\
8156 \\
\text { (87.6) } \\
\text { Girls: } \\
10960 \\
(95.6)\end{array}$ & $\frac{10030}{(48.3)}$ & $\begin{array}{c}\text { Boys: } \\
3578 \\
(38.4) \\
\text { Girls: } \\
6452 \\
(56.3)\end{array}$ & $\frac{7418}{(35.7)}$ & $\begin{array}{c}\text { Boys: } \\
2625 \\
(28.2) \\
\text { Girls: } \\
4793 \\
(41.8\end{array}$ \\
\hline Jews & $\underline{82783}$ & $\begin{array}{l}\frac{\text { Boys: }}{40234} \\
\frac{(48.6)}{\text { Girls: }} \\
\frac{42519}{(51.4)}\end{array}$ & $\frac{67805}{(81.9)}$ & $\begin{array}{l}\frac{\text { Boys: }}{32211} \\
\frac{(80.1)}{\text { Girls: }} \\
\frac{35594}{(83.7)}\end{array}$ & $\frac{47796}{(57.8)}$ & $\begin{array}{l}\frac{\text { Boys: }}{21186} \\
\frac{(52.7)}{\text { Girls: }} \\
\frac{26610}{(62.6)} \\
\end{array}$ & $\begin{array}{l}40833 \\
(40.3)\end{array}$ & $\begin{array}{l}\frac{\text { Boys: }}{18388} \\
\frac{(45.7)}{\text { Girls: }} \\
\frac{22445}{(52.8)}\end{array}$ \\
\hline TOTAL & 103528 & & $\begin{array}{l}86992 \\
(84.0) \\
\end{array}$ & & $\begin{array}{l}57826 \\
(55.9) \\
\end{array}$ & & $\frac{48251}{(46.6)}$ & \\
\hline
\end{tabular}

*The slight inconsistency (20775 vs. 20727) is due to the fact that a few dozens of Arab students do not belong to any of the 3 sub-groups: Muslims, Christian, or Druze.

\section{THE QUALITY OF THE MATRICULATION CERTIFICATE: COMPARISON BETWEEN CHRISTIANS AND JEWS}

In addition to taking the minimal 3-point mathematics examinations and the 4-point English exam as requirements to university acceptance, taking as many as possible high level subjects is necessary in order to get into many high prestige departments, and recommended for many others. Thus, high able students take as many as possible enhanced - 4+-point level - subjects. There are 4 combinations of the most prestigious subjects (David, 2002, 2008a):

\footnotetext{
${ }^{4}$ Processed from Statistics, Israel, 2012, table 8.24.
} 
- Two scientific subjects, two technological subjects and one humanistic subject;

- Two scientific subjects, one technological subject and one humanistic subject;

- Two scientific subjects and two technological subjects;

- One scientific subject, one humanistic subject and two technological subjects.

Table 2 shows the rate of taking each of these combinations among Christians and Jews.

Table 2. The matriculation certificate: Number of enhances subjects (4 units or more).

\begin{tabular}{|c|c|c|c|c|c|c|c|c|c|c|}
\hline \multirow{2}{*}{$\begin{array}{c}\text { Year } \\
\begin{array}{l}\text { Types of } \\
\text { subjects }\end{array}\end{array}$} & \multicolumn{5}{|c|}{ Christians } & \multicolumn{5}{|c|}{ Jews } \\
\hline & $\begin{array}{l}2 \text { science } \\
2 \text { human. }\end{array}$ & $\begin{array}{l}2 \text { science } \\
1 \text { hum. } \\
2 \text { tech. }\end{array}$ & $\begin{array}{l}2 \text { science } \\
1 \text { hum. } \\
1 \text { tech. }\end{array}$ & $\begin{array}{l}1 \text { science } \\
1 \text { hum. } \\
2 \text { tech. }\end{array}$ & total & $\begin{array}{l}2 \text { science } \\
2 \text { human. }\end{array}$ & $\begin{array}{c}2 \text { science } \\
1 \text { hum. } \\
2 \text { tech. }\end{array}$ & $\begin{array}{l}2 \text { science } \\
1 \text { hum. } \\
1 \text { tech. }\end{array}$ & $\begin{array}{c}1 \text { science } \\
1 \text { hum. } \\
2 \text { tech. }\end{array}$ & total \\
\hline $2011^{5}$ & 29.9 & 0.3 & 0.4 & 0.6 & 31.2 & 10.3 & 0.6 & 2.0 & 0.6 & 13.5 \\
\hline $2010^{6}$ & 30.2 & 0.4 & 0.8 & 0.6 & 32.0 & 10.6 & 0.6 & 2.1 & 0.6 & 13.9 \\
\hline $2009^{7}$ & 29.1 & 0.9 & 1.1 & 0.5 & 31.6 & 10.4 & 0.8 & 4.3 & 0.7 & 16.2 \\
\hline $2008^{8}$ & 27.2 & 0.9 & 0.8 & 0.2 & 29.1 & 10.5 & 0.7 & 4.1 & 0.7 & 16.0 \\
\hline $2007^{9}$ & 32.6 & 0.1 & 0.4 & 0.2 & 33.3 & 10.7 & 1.1 & 3.6 & 1.1 & 16.5 \\
\hline $2006^{10}$ & 32.5 & 0.3 & 0.6 & 0.2 & 33.6 & 10.6 & 1.0 & 3.1 & 1.4 & 16.1 \\
\hline $2005^{11}$ & 31.6 & 0.7 & 0.3 & 0.3 & 32.9 & 10.7 & 1.0 & 3.1 & 1.4 & 16.2 \\
\hline $2004^{12}$ & 35.1 & 0.5 & 0.6 & 0.1 & 36.3 & 11.1 & 0.9 & 1.6 & 1.5 & 15.1 \\
\hline $2003^{13}$ & 34.0 & 0.4 & 0.8 & 0.1 & 35.3 & 11.1 & 1.0 & 1.6 & 1.4 & 15.1 \\
\hline $2002^{14}$ & 32.3 & 0.7 & 0.8 & 0.1 & 33.9 & 10.8 & 0.8 & 2.0 & 1.4 & 15.0 \\
\hline $2001^{15}$ & 32.3 & 0.7 & 0.8 & 0.1 & 33.9 & 10.8 & 0.8 & 2.0 & 1.4 & 15.0 \\
\hline $2000^{16}$ & 34.5 & 0.2 & 1.1 & 0.2 & 36.0 & 10.6 & 0.8 & 1.9 & 1.3 & 14.6 \\
\hline $1998^{17}$ & 32.0 & 0.6 & --- & 0.5 & 33.3 & 11.0 & 0.8 & 1.6 & 1.3 & 14.7 \\
\hline
\end{tabular}

This table shows that the quality of the matriculation certificate of the high school Christian graduate is much better than that held by the Jewish high school graduate. Almost 3

\footnotetext{
${ }^{5}$ Statistics, Israel, 2012, table 8.26.

${ }^{6}$ Statistics, Israel, 2011, table 8.25.

${ }^{7}$ Statistics, Israel, 2010, table 8.25.

${ }^{8}$ Statistics, Israel, 2009, table 8.25 .

${ }^{9}$ Statistics, Israel, 2008, table 8.26.

${ }^{10}$ Statistics, Israel, 2006, table 8.23

${ }^{11}$ Statistics, Israel, 2005, table 8.22.

${ }^{12}$ Statistics, Israel, 2004, table 8.22.

${ }^{13}$ Statistics, Israel, 2003, table 8.22.

${ }^{14}$ Statistics, Israel, 2002, table 8.24.

${ }^{15}$ Statistics, Israel, 2001, table 8.24.

16 Statistics, Israel, 2000, table 22.25.

${ }^{17}$ Statistics, Israel, 1999, table 22.24.
} 
times more Christians than Jews take 2 high-level examinations belonging to the "humanities" group. Taking into consideration that in all Christian institutes there are at least 3 obligatory languages (Arabic, Hebrew, and English), the students who take just 2 of them as enhanced subjects already fulfill the "2 enhances humanistic subjects" condition.

\section{CHRISTIAN FEMALES}

Palestinian girls have traditionally had good access to high quality education if they lived in large Arab cities. For example, the first girls' school was established in Nazareth, which presently serves as the capital for Arabs living in the northern areas of Israel. The Nazareth Nuns' School was founded in 1855 in the large, wealthy, economically and socially developed Christian-Arab town (Sisters of Nazareth, 2013). A second Christian School, the first Arab school for girls, opened in Haifa in 1858 (Ratner, 2005). Haifa was at that time an Arab town with a majority of Muslims, about $15 \%$ Christians and a small minority of Jews. Today this school has about 1500 students, and includes three sections: Kindergarten: 3 to 5 year old children; Primary school: 6 to 12 year old children, and The Middle and High school: 13 to 18 years old (Sisters of Nazareth School, Haifa, 2013).

Female Arabs in Israel - including Christians - have always had to stay within the borders of tradition while advancing in all social, financial and educational aspects of life (David, 2013).

Although Christian women were generally able to pursue high school and academic education as a result of a free education offered by Christians denomination that arrived at Palestine since the middle of the seventeenth century (Abu-Baker, 1998), this study found that Christian marital norms and gender roles were comparable to those of Muslim and Druze women. This means that Arabic culture and traditions, influenced by Islam, have been the dominant factor impacting family and social relationships and norms among Palestinians in Israel (Abu-Baker \& Azaiza, 2010, p. 175).

Let us look at some examples of schools that had contributed to the advancement of Arab students in general - intended originally for Christians but turned into multi-religion institutions.

The two Nazareth Nuns' Schools have a long tradition of academic excellence. They are both co-educational: in 2006 girls comprised 52\% of the graduating class. The school's achievements have been impressive by all criteria. In 2002, the general eligibility for the matriculation certificate for Israelis and Arabs in Israel was just 55.5\% and 51.5\% respectively (Statistics, Israel, 2004, table 8.21). In that year over 95\% of The Nazareth Nuns' School graduates were entitled to the matriculation certificate, scoring second highest among all Israeli schools (Ilan, 2002).

No less impressive are the most recently published achievements of this school in the matriculation examinations. In 2006, $75 \%$ of the school's graduates continued their higher education in the most prestigious Israeli faculties. In contrast, on that year less than $46 \%$ Israeli high school graduates met university requirements, and in the Arab sector - just 35\% (Statistic, Israel, 2007, table 8.24). Overall, the achievements of girls from this school have been remarkable, supplying, for example, the Technion, Israel Institution of Technology, with the largest number of females who were accepted to its various scientific departments (Sisters of Nazareth School, Haifa, 2013).

These institutions are examples of those that have always been run by a Christian organization. They have served all the Arab population, enabling many youngsters, especially 
young women who have not been able to leave their homes, to get high quality education. Take, for example, the Orthodox School in Haifa: Over 50\% of its students at have been Muslim. The remaining 50\% are Christians, Druze and Bedouin from all over Israel (Ratner, 2005). The school has a dormitory for male students, but for its female students it arranges reliable transportation allowing many of them come to Haifa from a variety of northern Arab cities and villages.

We can thus conclude that those most likely to have benefitted from the openness of these high quality Christian schools have been Muslim Arab girls. While in the $19^{\text {th }}$ century only upper middle- and high class Muslims would have considered sending their daughters to these schools, nowadays a unique cooperation between the Christian educational institutions and the parents of young Muslim girls allows for almost all talented girls living in the northern part of Israel to acquire excellent education. Many of the Christian schools offer grants to students from a low socio-economic background. In addition, transportation to school makes it possible for many girls, who cannot use public transportation because of traditional reasons, to arrive safely at school and benefit from the opportunity to concentrate on developing their intellectual abilities.

\section{THE ACHIEVEMENTS IN CHRISTIAN SCHOOLS - SINCE 2000}

In 2000 Christian Arab schools were ranked by matriculation entitlement as follows (Weingard, 2001):

1. St. Joseph Nuns in Nazareth: $97.52 \%$;

2. Nazareth Nuns in Haifa, $95.16 \%$;

3. The Arab Orthodox School in Haifa, $90.63 \%$;

4. The Franciscan Nuns in Nazareth, $88.04 \%$;

5. The Baptist High School in Nazareth, $84.8 \%$.

In 2002 the results of students learning in Christian schools - especially those of Christians - improved and made new Israeli records. Of the top 4 Haifa schools, the Nazareth Nuns scored first with a 98-percent pass rate in the matriculation exams; The Orthodox School was in third place, with a 95-percent pass rate (Ratner, 2005).

Citing headmaster Kabour of the Orthodox School in Haifa, Ratner (ibid) explains that not only was entitlement so high but "over $45 \%$ of the students achieved sores of 10 or more on the exams". In addition over $70 \%$ of each year graduating class completes university education.

According to Rotem (4/11/2006), in 2005 three of the five Israeli schools with the best achievements in the matriculation examinations were Christian. One of them was the Arab Orthodox School in Haifa. This school has very crowded classes, about 40 students in each, and it applies old-fashioned, traditional ways of teaching. In spite of that its achievements have been among the highest in Israel whenever measured. In addition, though the school focuses on science and technology, the girls achieve higher grades than the boys (ibid). 


\section{CURRENT ACHIEVEMENT OF CHRISTIAN SCHOOLS}

There are about 30 Christian schools in Israel (ibid). They all share a high quality staff members - especially highly educated teachers, who are dedicated to their work and to their best to work individually with each student. Let us discuss dome examples.

The Arab Orthodox School in Haifa is up to now one of the best schools in Israel. In 2010 it ranked at the highest, $10^{\text {th }}$ decile in all educational measures. $98.16 \%$ of its graduates were eligible to the Matriculation certificate; $23.31 \%$ of its students achieved and excellent matriculation certificate; $100 \%$ of its students passed the high level English matriculation examination, all levels Hebrew matriculation examinations, as well as the civic and history examinations - all obligatory in the Israeli education system; $82.2 \%$ of the students passed the high level math examination, and $93.9 \%$ passed the mother-tongue examination (Everything about educational institutes: the Arab Orthodox School in Haifa, 2011). The matriculation examination in Arabic, which is the mother tongue of Arabs is Israel, is considered especially hard for Arab students, because spoken Arabic is different from the literary language on which they are examined (David, 2002), and even harder for Arabs learning in a multi-lingual school, with at least 3 languages; Arabic, Hebrew, English, and in most cases an additional language, such as French or Italian, in particular.

St. Joseph nuns in Haifa also ranked in 2010 at the highest, $10^{\text {th }}$ decile in all educational measures. $94.6 \%$ of its graduates were eligible to the matriculation certificate; $17.4 \%$ of the students were ranked as "excellent"; $100 \%$ of the students passed the highest level English matriculation examination, the civic examination, as well as the Hebrew and history examinations - all obligatory subjects for eligibility to an Israeli matriculation certificate; $67.4 \%$ passed the highest level math examination, and 99\% passed the mother-tongue examination (Everything about educational institutes: St. Joseph Nuns in Haifa (2011).

Even the Italian School in Haifa (Everything about educational institutes: The Italian School in Haifa, 2010), never ranking at the top of achievement among Christian schools, ranks at the highest Israeli decile; with $79.4 \%$ eligibility to the Israeli matriculation certificate, $16 \%$ of excellent students, $89 \%$ of the students passing the highest level English examinations, $46 \%$ of the students passing the highest level math examination, $87.3 \%$ passing the civic matriculation examination, 93.65\% passing the Hebrew examination and $90.5 \%$ passing all levels of history examination.

\section{EXCELLENCE IN THE MATRICULATION EXAMINATIONS: CHRISTIAN SCHOOLS}

A high school graduated is considered an "excellent student" if her or his average grade in the matriculation certificate is at least 90 consisting of at least the highest possible level of English and Mathematics (The Israeli Ministry of Education, the technological-scientific reserve, 2010). The Israeli average of excellent students stood at 4\% of the age group in 2009 (ibid); thus it is quite remarkable that in some Christian schools the rate of excellent students was 8 times higher.

For example: According to Zemer (13/10/2008), in 2006 three of the Christian schools in Nazareth had the highest rates of excellent students, as measured by both the quality of the matriculation certificated and the grades their graduates had earned. St. Joseph school in Nazareth has 33.3\% excellent students; St. Joseph nuns in Nazareth had 30.56\% excellent students, and the Baptist high school in Nazareth had 30.91\% of excellent students. 
St. Joseph School, Nazareth (2012), has known to be an excellent school for many decades according to its achievements in the matriculation examinations. Each year this institute receives an appreciation letter from the Israeli Ministry of Education for its excellence in a variety of subjects. In 2010 the school had the best achievements in Israel in computer sciences.

In addition, the school helps each student and prevent dropout, in spite of the fact that $12 \%-15 \%$ of the students have special needs. The population of the school is mixed: about two thirds are Christians; one third is Muslim and a few are Druze. One third of the teachers are Muslim as well, the majority are Christians (ibid).

A notable achievement of a female student of one of the Christian schools in Israel have been just published. 4 Israeli youngsters won a bronze medal in the Chemistry Olympiad taken place in Moscow in August 2013: 3 Jewish boys and one Arab girl, Marah Zouabi, an 11 ${ }^{\text {th }}$ grade student at the St. Joseph high school in Nazareth (The International Chemistry Olympiad, 2013).

Christian women have been able to walk on the narrow road between tradition and modern life. They have been more successful during all levels of education in comparison both to Israeli Jewish women and in comparison to Christian men. For example: in 2011 the percentage of Christian female university students has been higher than in all other sectors (Meniv, 2011). Among first degree students, females consisted of $63.0 \%$ in comparison to $55.9 \%$ in the general population; among second degree students Christian females consisted of $67.9 \%$ in comparison to $57.9 \%$ in the general population, and among $\mathrm{PhD}$ students $-53.8 \%$ were women in comparison to $52.7 \%$ in the general population (ibid).

\section{GIFTED ARAB STUDENTS: NO PUBLIC CLASSES}

Identification for giftedness in Israel takes place in grade 2 or 3, and includes all children, Jews and Arabs, ${ }^{18}$ living in all municipalities and school types. However, while in the Jewish public sector there are a few elementary schools with special classes for the gifted and more than 100 high school classes for the gifted, no such classes exist in the Arab sector.

The need of high level education has a high priority in the Arab sector, as can be obvious by the fact that many Thousands of families - both Christian and Muslim - finance the tuition for their children in the excellent Christian institutions (David, 2008a, 2008b, 2009a, 2009b), and in light of the substantial gaps between the level of the public Jewish and Arab schools (David, 2008a; Kashti, 2011; "Meitzav", 2010; Velmer, 2010; Zelikovich, 2009). Thus it should be wondered why in the sector most in need there are no public classes for the gifted.

The compensation for the lack of appropriate programs for Arab gifted students has been excellent Christian schools open to both Muslim and Christians. These institutions have been functioning for high school gifted students, both Christians and Muslims. No wonder "the percentage of Arab Christians entitled to the matriculation certificate and are eligible to university education is higher than that of Jews, Muslims and Druze" (National Council for the child, 2010, p. 10).

One such school located outside of the main Christian centers in Israel is The Mar Elias School in Ibillin (2012). The high school is considered the centerpiece among the Mar Elias Institutions. More than 1200 students from all over the Galilee enroll in its classes;

\footnotetext{
${ }^{18}$ Currently most East Jerusalem children are not identified for giftedness, as well as the Bedouins in the Negev (David, 2013).
} 
the school is known to be one of the best 4 schools in Israel. It should be noted that though the school is Christian, belonging to the Galilee diocese of the Catholic Church, about two thirds of its students are Muslim (ibid).

The students of Mar Elias High are encouraged to participate in programs which, among others, try to establish long term relationships with people from other backgrounds, such as Jews, Italians and Americans.

The students are asked to choose a major during the beginning of the 10th grade. The main subjects currently taught at Mar Elias High include:

- Physics

- Biotechnology

- Electronics

- Computer Science

- Chemistry

- Biology

- Sports

- Ecology

- Psychology

\section{CHRISTIAN ARABS IN HIGHER EDUCATION}

In the 2011/2012 school year, some 5,700 students affiliated with Christianity studied in one of Israel's higher education institutes and comprised $1.8 \%$ of Israel's student population. The highest participation of Christian students was in medical studies. $2.5 \%$ of the Christian Arab students studied medicine, in comparison to only $0.8 \%$ of all students; $10.1 \%$ of the Christian Arab students studied paramedical studies in comparison to only $4.4 \%$ of all BA students in Israel. On the other hand, while in the general population $17.1 \%$ of the students studied engineering, among Christian Arabs this rate was only 12.8\%. This has, probably, to do with the fact that regarding medicine and medical professions, there is no discrimination in the workplace in Israel. In the Galilee, the northern part of Israel, the vast majority of doctors and nurses are Arabs, both Christians and Muslims who had studied in Israel, and Druze, who had studied in Syria. ${ }^{19}$

The median age of first degree Christian students was 22.3 in comparison to 25.3 in the general population; the median age of second degree Christian students was 27.9 in comparison to 30.4 in the general population, and the median age of $\mathrm{PhD}$ Christian students was 32.8 in comparison to 33.4 in the general population. The reason is the fact that Christian Arabs - as Arabs in general - do not have to do compulsory military service, standing at 3 years for males and 2 years for females in the Jewish sector. This age gap gives the Christian students an

\footnotetext{
${ }^{19}$ Due to the last event in Syria, the Druze students living in the Golan Hights and studying in Damascus have faced a serious problem. In summer 2013 not all of them returned home to Israel, in fear they would not be allowed to go back to Syria to finish their studies (Ya'ar, 12.7.2013). Most students who returned to Israel decided to stay in it. However, medical students, who were promised they would be able to continue their studies either at the Tel Aviv University or at the Bar Ilan University, were denied when requiring their comprehensive record of courses and grades from the University of Damascus. Thus, their dilemma was whether to give up their long studies and training or risk their lives (Hashmonai, 18/8/2013). On August 21, 2013, 35 very brave students returned to Syria a few hours after the chemical attack to continue their studies in Damascus (Hashmonai, 22/8/2013).
} 
advantage over Jewish, an advantage they have wisely used for improving their educational and financial standing.

\section{CONCLUSION}

Christian Arabs are "a minority within a minority" in Israel. However, they are the most educated sub-population; they have a high presentation in science and in the professions, and they contribute a lot to the advancement of all Arabs in Israel by opening their private, high level educational institutions to all good students, regardless of religion or ethnic origin.

Unlike the norms most common in Israeli institutions of education the main values according to which education is applied in these excellent schools are of hard work - both of the students and the teachers, rigid discipline, old-fashioned ways of teaching in crowded classes, and rewarding achievements that are the result of intensive, consistent investment.

\section{References}

[1] Abu-Baker K. (1998). On unpaved Road: About successful women in Israel. Ra'anana: Center for the study of Arab society in Israel

[2] Abu-Baker K., Azaiza F. (2010). Strategies for closing the educational gaps among Palestinian couples in Israel. Journal of women in the Middle East and the Islamic World, 18, 154-180.

[3] Christians 2011 - Christians in Israel: Press Release (Hebrew) (25/12/2011). The Central Bureau of Statistics. Retrieved on 16 August 2012 from: www.cbs.gov.il/www/hodaot2011n/11_11_328b.doc

[4] David H. (2002). A minority within a minority: Mathematics, science and technology studies among Israeli and Arab female students. In L. Maxwell, L. Slavin, \& K. Young (Eds.), Proceedings of The Gender and Science Conference, Brussels, 8-9 November, 2001 (pp. 248-255). Brussels: The European Commission.

[5] David H. (2008a). Educational gaps between Jews and Arabs in Israel. Al-Nibras, Articles in Education, Science \& Society, 4, 35-53.

[6] David H. (2008b). Gifted females in science: The Israeli case. Al-Nibras, Articles in Education, Science \& Society, 4, 54-63.

[7] David H. (2009a). The influence of gender, religion, grade, class-type, and religiosity on mathematical learning in the Israeli junior high school. Saarbrücken, Germany: VDM Verlag.

[8] David H. (2009b). The Arab gifted child in Israel: Book summary. Gifted Education Press, 23(4), 9-15.

[9] David H. (2013). The Arab gifted child in Israel. Ulm, Germany: ICIE: International Centre for Innovation in Education.

[10] Druckman Y. (23.12.2012). Christians in Israel: Strong in education. Retrieved on 15 August 2013 from http://www.ynetnews.com/articles/0,7340,L-4323529,00.html 
[11] Everything about educational institutes: the Arab Orthodox School in Haifa (25/07/2011). Retrieved on 28 August 2013 from: http://hinuch.education.gov.il/imsnet/PirteiMosad.aspx?Sm=347013

[12] Everything about educational institutes: The Italian School in Haifa (25/07/2011). Retrieved on 28 August 2013 from:

http://hinuch.education.gov.il/imsnet/PirteiMosad.aspx?Sm=347039

[13] Everything about educational institutes: St. Joseph Nuns in Haifa (25/07/2011). Retrieved on 28 August 2013 from:

http://hinuch.education.gov.il/imsnet/PirteiMosad.aspx?Sm=347021

[14] Fridman I. (2011). The relationship between education and successful marriage. Jerusalem: Central Bureau of Statistics - The Chief Scientist Department working Paper Series, No. 63 (in Hebrew).

[15] Hashmonai A. (18/8/2013). The dilemma of Druze students is escalating. http://www.nrg.co.il/online/1/ART2/500/037.html

[16] Hashmonai A. (22/8/2013). Druze students [from the Golan Heights] returned to Syria. Retrieved on 25 August 2013 from http://www.nrg.co.il/online/54/ART2/501/630.html

[17] The International Chemistry Olympiad (2013) (Hebrew). Retrieved on 27 August 2013 from http://cms.education.gov.il/EducationCMS/Units/Mazkirut_Pedagogit/Chimya/Eruaim/ olympiada_2013.htm

[18] The Israeli Ministry of Education, the technological-scientific reserve (August 2010). Retrieved on 28 August 2013 from the Israeli Ministry of Education web: cms.education.gov.i1/NR/.../a_m_technologit.pps

[19] Kashti O. (22/2/2011). Study: Arab students invest more homework. Retrieved on 13 July 2013 from http://www.haaretz.co.il/news/education/1.1163360

[20] Kashti O. (14/3/2011). Analysis of the MEITZAV: Geometry grades have been [ebb, low tide, low point] (Hebrew). Retrieved on 8 December 2011 from: http://www.haaretz.co.il/news/education/1.1166616

[21] Lehrer E. L. (2006). Age at Marriage and Marital Instability: Revisiting the BeckerLandes Michael Hypothesis. Discussion Paper No. 2166, IZA, Germany.

[22] The Mar Elias School in Ibillin (25.8.2012). Retrieved n 26 August 2013 from: http://www.peopleil.org/details.aspx?itemID $=30157$

[23] "Meitzav" [a Hebrew acronym for school efficiency and growth indices] 2010: Part Iachievements examinations. School efficiency and growth indicators from 2010 (Hebrew). Jerusalem: The Ministry of Education, The National Authority for. Measurement and Evaluation in Education, Israel.

[24] Meniv O. (28.12.2011). Christian schools most successful in Israel. Retrieved on August 25, 2013 from:

http://www.catholic.co.il/index.php?option=com_content\&view=article\&id=1249:chris tian-schools-most-successful-in-israel\&catid=9:-articles\&Itemid=15\&lang=it

[25] National Council for the child (22/12/2010). Data collection from the annual: Children in Israel - 2010 . 
[26] Ratner D. (2005). Haifa's Christian schools lead the league. Haaretz, 9/2/2005. Available online at: http:/www.haaretz.com/hasen/pages/ShArt.jhtml?itemNo=431603\&contrassID $=2 \&$ sub ContrassID $=20 \&$ sbSubContrass ID $=0 \&$ listSrc $=Y$

[27] Rotem, T. (4/11/2006). The silent revolution of the young Arabs: Education. Retrieved on 27 August 2013 from: http://news.walla.co.il/?w=/90/1002179

[28] Sisters of Nazareth School, Haifa (2013). Retrieved on 27 August 2013 from: http://www.sistersofnazarethkindergarten-haifa.org/?todo=vision\&tid=11

[29] Sisters of Nazareth School, Nazareth (2013). Retrieved on 27 August 2013 from: http://holylandcgh.org/guesthouses/Nazareth/sisters_of_nazareth/index.htm

[30] St. Joseph school, Nazareth (21/1/2012). Retrieved on 27 August 2013 from http://www.ssjs-nazareth.org/ssjs/ar/index.aspx (Arabic) and from http://www.peopleil.org/details.aspx?itemID=30334 (Hebrew).

[31] Statistics, Israel (2012). Yearbook of Statistics, 63. Jerusalem, Israel: The Central Bureau of Statistics. Retrieved on July 222013 from http://www.cbs.gov.il/reader/shnaton/templ_shnaton.html?num_tab=st08_24\&CYear=2 012

[32] Statistics, Israel (2011). Yearbook of Statistics, 62. Jerusalem, Israel: The Central Bureau of Statistics.

[33] Statistics, Israel (2010). Yearbook of Statistics, 61. Jerusalem, Israel: The Central Bureau of Statistics,

[34] Statistics, Israel (2009). Yearbook of Statistics, 60. Jerusalem, Israel: The Central Bureau of Statistics.

[35] Statistics, Israel (2008). Yearbook of Statistics, 59. Jerusalem, Israel: The Central Bureau of Statistics.

[36] Statistics, Israel (2006). Yearbook of Statistics, 57. Jerusalem, Israel: The Central Bureau of Statistics.

[37] Statistics, Israel (2005). Yearbook of Statistics, 56. Jerusalem, Israel, The Central Bureau of Statistics.

[38] Statistics, Israel (2004). Yearbook of Statistics, 55. Jerusalem, Israel, The Central Bureau of Statistics.

[39] Statistics, Israel (2003). Yearbook of Statistics, 54. Jerusalem, Israel, The Central Bureau of Statistics.

[40] Statistics, Israel (2002). Yearbook of Statistics, 53. Jerusalem, Israel, The Central Bureau of Statistics.

[41] Statistics, Israel (2001). Yearbook of Statistics, 52. Jerusalem, Israel, The Central Bureau of Statistics.

[42] Statistics, Israel (2000). Yearbook of Statistics, 51. Jerusalem, Israel, The Central Bureau of Statistics.

[43] Statistics, Israel (1999). Yearbook of Statistics, 50. Jerusalem, Israel, The Central Bureau of Statistics. 
[44] Talal D., Ben Rabi D. (February, 2001). Initial Periodic Report of the State of Israel Concerning the Implementation of the Convention on the Rights of the Child (CRC). State of Israel Ministry of Justice, Ministry of Foreign Affairs. Retrieved on 26 August 2013 from: http://www.justice.gov.il/NR/rdonlyres/129A5B6A-20D6-4C3B-97851C6B6763394A/0/CRCengfull.pdf

[45] Weingard E. (2001). Learning in the hard way. Ha'Ir [=The City], 22 November, 2001 (Hebrew).

[46] Ya'ar C. (12.7.2013). Syria: Not All Druze Students Return Home to Israel. Retrieved on 25 August 2013 from:

http://www.israelnationalnews.com/News/News.aspx/169836\#.UhmQJdJHJ2A

[47] Velmer T. (21/9/2010). Ynet special: Israel's education woes. Retrieved on 13 July 2013 from: http://www.ynetnews.com/articles/0,7340,L-3958211,00.html

[48] Zelikovich Y. M. (2009). The "Meitzav" [a Hebrew acronym for school efficiency and growth indices] examinations: A growing gap between Arabs and Jews Hebrew).

Retrieved on 8 December 2011 from

http://www.ynet.co.il/articles/0,7340,L-3809995,00.html

[49] Zemer E. (13/10/2008). To be a student: The schools who earned the best reputations. Retrieved on 27 august 2013 from: http://www.nrg.co.il/online/16/ART1/798/532.html

[50] Kabiru Ibrahim Yankuzo, International Letters of Social and Humanistic Sciences 4 (2014) 1-8.

[51] S. A. Kazeem, K. Y. Balogun, International Letters of Social and Humanistic Sciences 8(2) (2014) 108-119.

[52] Hakeem A. Akitoye, International Letters of Social and Humanistic Sciences 14 (2014) 42-49.

[53] Andrzej Borowski, International Letters of Social and Humanistic Sciences 11 (2014) 1-168. 